\title{
Macrothink

\section{Evaluation of Impact of Motion and Time on Employees' Job Satisfaction in Goldasht Mosaic Plant}

\author{
Hossein Khani \\ Department of Management, Islamic Azad University, Najafabad branch, Najafabad, Iran
}

Mohammad Hossein Moshref Javadi, Ph.D.

Assistant Professor of business administration

University of Isfahan, Isfahan, Iran (Islamic Republic)

Accepted: October 2, 2011 Published: December 4, 2011

Doi:10.5296/ijld.v1i1.1132ＵRL: http://dx.doi.org/10.5296/ijld.v1i1.1132

\begin{abstract}
The present survey is about evaluation of motion and time with regard to job satisfaction in Isfahan Goldasht Mosaic Plant. There are five hypotheses in this survey: The main hypothesis is that evaluation of motion and time affect wage. Five factors of job satisfaction and their impact on job satisfaction were studied in the secondary hypotheses. This survey was conducted using descriptive-field method and data was collected by means of questionnaire, interview and observation. Statistical population of Goldasht Mosaic Plant included onehundred forty (140) persons in which statistical sample in this survey were equal to the statistical population. Statistical techniques and SPSS software were used for data analysis. Motion measurement and timing procedures like OPC process and process of working with both hands were applied to evaluate motion and time. Research findings indicated that evaluation of motion and time had positive impact on wage, while it must be pointed out that other four secondary hypotheses established the following points: Evaluation of motion and time had negative impact on improvement opportunity, nature of work and supervision. But it had positive impact on colleagues. Recommendations about considering organizational performance and job satisfaction regarding productivity of employees were represented at the end of survey given research findings.
\end{abstract}


Key words: Evaluation of motion and time, motion measurement, timing, job satisfaction

\section{Introduction}

Motion studying is considered as a tool in books regarding work execution control and improvement of efficiency and productivity as well as improvement of return on investment. In addition, studying strategies and effective methods for maximum application of technical, engineering, productive and executive capability in organizations and institutions in order to implement projects is among discussing issues in work evaluation. Today studying the motion ground and explaining its characteristics is one of the important issues that could be negotiated in the organizations.

In addition to evaluation of trainees, dissatisfaction of employees from inattention to the issue of human force in factories is one of the major issues in current factories. Most of the factory owners pay attention to increase profitability, efficiency and productivity but employees' job satisfaction that is one of the most important issues about labor force is usually not taken in to the consideration.

Most organizations especially those with traditional service enjoy structure that has been formed during the time. This issue is leaded to increase various costs especially in the personnel section that is arising from human force inflation, variance levels and lack of accurate arrangement and balance in using of it, hence decreases efficiency and as a result productivity. The result is reduction in total return of capital.

Significant result of such phenomenon is increased cost price of the product unit period. Thus the researchers intended to estimate required human force of various units in the company and studying work which can cause saving costs.

\section{Research methodology}

This survey was conducted using descriptive-field methodology with regards to the nature of research and intended statistical population. Research literature was compiled by means of books and information from websites as well as results of researches related to the subject. Tools of data collection included observation, and a questionnaire in which necessary data and information were collected from the statistical samples.

Therefore, a questionnaire has been prepared based on research literature and by considering views and recommendations of guiding and advising professors. 
Questionnaires were anonymous and questions were designed in a closed form. Responding to these questions didn't take much time and in fact facilitation in responding attracted respondents' attention and focus on the subject. Anonymity of the questionnaire attracted respondent's confidence and peace of mind so that they would represent more accurate responses with more freedom.

\section{Statistical population}

All of The Goldasht Mosaic Plant personnel were studied in this survey, which included:

1- Repair section 2- Sales office 3- Stone powder mill 4- Electricity workshop 5Warehouses 6- Nari 7- Press section 8-Get water 9- Blotting 10- Saab unit.

It is noteworthy that sum of the existing samples in this study was equal to one-hundred forty (140) persons.

\section{Statistical sample}

According to experts view of industrial engineering group of the factory all ten sectors in this plant have been studied. Sum of the factory personnel in these sections was equal to onehundred forty (140) persons, in which this survey is based on. Therefore, Statistical sample in the present research was equal to the statistical population in which all of the statistical population was studied.

\section{Method of data collection}

Generally, method of data collection in order to evaluate motion and time is in the form of field study through (analyzing one of the jobs, discovering, studying and recording essential aspects of each job) and in terms of production process type (discontinuous, continuous, batch production) that could be performed as one of the following methods or a combination of them.

1- Usual timing with chronometer that has the highest application in assembly production lines.

2- Using PTS standards for monotonous activities

3- Time simulation methods for similar activities with high variety

4- Referring to job descriptions and separation of tasks and their time estimation: administrative sections having monotonous activities are evaluated with this method.

5- Using maintenance parameters 
6- Using fabrication formula and equations in estimation of consumption time

7- Evaluating motion volume of each section by help of evaluation results of neighboring sections: This method is applied partially in exploitation sections of continuous production lines in which evaluation can't be performed independently.

\section{Adjusting the questionnaire based on test characteristics}

Questionnaires are anonymous and questions are designed in a closed form. Designing such questions is useful in saving the respondent's time, attracting his attention and focus while anonymity of the questionnaire attracts respondent's confidence and peace of mind so that he will represent more accurate responses with more freedom.

Likert scale has been used for responding the questions.

Questionnaire is composed of the two following sections:

A) questions related to general specifications

B) questions related to job satisfaction

\section{A) questions related to general specifications:}

The questionnaire has been designed with five closed questions about personal specifications of respondents in order to gain primary information from members of the statistical population. These include information about relative status, marital status, work experience, education level and amount of received salary and benefits.

\section{B) questions related to job satisfaction:}

Two sets of questions have been proposed in this section. Job description scale of Smith Kendul and Hyline University are used to design these questions and then are used to measure job satisfaction.

This index represents a group of properties as probable descriptions related to five dimensions of job. These dimensions are the most important job characteristics that individuals show positive reaction against them (Lutenz Fred, 1998, p 177).

Five dimensions of job description are: 
1- Work nature and conditions: it means the existing characteristics in tasks and working conditions of the individual.

2- Wage and salary: it is the amount of financial execution that the individual receives with regard to performed work.

3- Opportunity of promotion: it is the opportunity of progress in the organizational hierarchy.

4- Supervision: it is the manner of relation of the individual with his direct supervisor and capability of the supervisor in offering behavioral support and technical assistance to the individual.

5- Job colleagues: it is the degree according to which colleagues are efficient technically and are supporter of the individual socially.

Reliability of job satisfaction questionnaire was examined through valuation test that reliable coefficient obtained was equal to $9 \%$.Therefore, it is concluded that the questionnaire had a reliable validity, since it was above $7 \%$.

\section{Distribution and collection of questionnaires}

One-hundred forty (140) questionnaires were prepared and distributed to the statistical population of survey and after distribution one-hundred thirty eight (138) questionnaires were collected by cooperation of managers of the related units.

\section{Statistical methods}

Applied statistical methods of analyzing data included inferential statistics of dependent $\mathrm{t}$ test. In addition to statistical indexes like frequency, percentage, mean and standard deviation were also applied.

\section{Findings}

Findings are represented in this section and in tables 1 to 5 according to the research hypotheses.

Research hypothesis 1: Implementation of motion and time evaluation affects work nature component of job satisfaction. 
Table 1- Results of dependent t-test, comparing average amount of scores before and after motion and time evaluation related to work nature component of job satisfaction

\begin{tabular}{|l|c|c|c|c|c|c|c|}
\hline \multicolumn{1}{|c|}{$\begin{array}{c}\text { Statistical } \\
\text { indexes }\end{array}$} & Mean & $\begin{array}{c}\text { Standard } \\
\text { deviation }\end{array}$ & df & $\begin{array}{c}\text { Paired } \\
\text { average }\end{array}$ & $\begin{array}{c}\text { Paired } \\
\text { standard } \\
\text { deviation }\end{array}$ & $\mathbf{t}$ & $\begin{array}{c}\text { Significance } \\
\text { level }\end{array}$ \\
\hline $\begin{array}{l}\text { Variable } \\
\text { of motion and } \\
\text { time evaluation }\end{array}$ & 23.73 & 4.86 & 137 & 0.71 & 5.46 & 1.53 & 0.13 \\
\hline $\begin{array}{l}\text { After evaluation } \\
\text { of motion and } \\
\text { time }\end{array}$ & 23.02 & 5.67 & & & & & \\
\hline
\end{tabular}

According to obtained results the observed $\mathbf{t}$ doesn't show a significant difference between average amount of work nature component before and after motion and time evaluation at level $\mathrm{P}<5 \%$. Thus, implementing motion and time evaluation plan can not affect nature of work therefore, first hypothesis is rejected.

Research hypothesis 2: Implementation of motion and time evaluation affects wage component of job satisfaction.

Table 2- Results of dependent t-test, comparing average amount of scores before and after motion and time evaluation related to wage component of job satisfaction

\begin{tabular}{|l|c|c|c|c|c|c|c|}
\hline \multicolumn{1}{|c|}{$\begin{array}{c}\text { Statistical } \\
\text { indexes }\end{array}$} & Mean & $\begin{array}{c}\text { Standard } \\
\text { deviation }\end{array}$ & $\begin{array}{c}\text { Paired } \\
\text { average }\end{array}$ & $\begin{array}{c}\text { Paired } \\
\text { standard } \\
\text { deviation }\end{array}$ & $\mathbf{t}$ & $\begin{array}{c}\text { Significance } \\
\text { level }\end{array}$ \\
\hline $\begin{array}{l}\text { Vefore evaluation } \\
\text { of motion and } \\
\text { time }\end{array}$ & 9.02 & 2.36 & \multirow{2}{*}{137} & 2.21 & 2.11 & 12.27 & 0.001 \\
\hline After evaluation & 11.23 & 2.20 & & & & \\
\hline
\end{tabular}




\begin{tabular}{l|}
\hline $\begin{array}{l}\text { of motion and } \\
\text { time }\end{array}$ \\
\hline
\end{tabular}

According to obtained results the observed $\mathbf{t}$ doesn't show a significant difference between average amount of wage component before and after motion and time evaluation at level $\mathrm{P}<5 \%$. Thus, implementing motion and time evaluation plan can not affect wage there fore, second hypothesis is confirmed.

Research hypothesis 3: Implementation of motion and time evaluation affects job promotion opportunity component of job satisfaction.

Table 3- Results of dependent t-test, comparing average amount of scores before and after motion and time evaluation related to job promotion opportunity component of job satisfaction

\begin{tabular}{|l|c|c|c|c|c|c|c|}
\hline \multicolumn{1}{|c|}{$\begin{array}{c}\text { Statistical } \\
\text { indexes }\end{array}$} & Mean & $\begin{array}{c}\text { Standard } \\
\text { deviation }\end{array}$ & df & $\begin{array}{c}\text { Paired } \\
\text { average }\end{array}$ & $\begin{array}{c}\text { Paired } \\
\text { standard } \\
\text { deviation }\end{array}$ & t & $\begin{array}{c}\text { Significance } \\
\text { level }\end{array}$ \\
\hline $\begin{array}{l}\text { Before evaluation } \\
\text { of motion and } \\
\text { time }\end{array}$ & 16.41 & 3.42 & 137 & 0.39 & 3.72 & 1.24 & 0.22 \\
\hline $\begin{array}{l}\text { After evaluation } \\
\text { of motion and } \\
\text { time }\end{array}$ & 16.02 & 4.087 & & & & & \\
\hline
\end{tabular}

According to obtained results the observed $\mathbf{t}$ doesn't show a significant difference between average amount of job promotion opportunity component before and after motion and time evaluation at level $\mathrm{P}<5 \%$. Thus, implementing motion and time evaluation plan can not affect job promotion opportunity and third hypothesis is rejected.

Research hypothesis 4: Implementation of motion and time evaluation affects supervision component of job satisfaction. 
Table 4- Results of dependent t-test, comparing average amount of scores before and after motion and time evaluation related to supervision component of job satisfaction

\begin{tabular}{|c|c|c|c|c|c|c|c|}
\hline $\begin{array}{l}\text { Statistical } \\
\text { indexes }\end{array}$ & Mean & $\begin{array}{l}\text { Standard } \\
\text { deviation }\end{array}$ & df & $\begin{array}{c}\text { Paired } \\
\text { average }\end{array}$ & $\begin{array}{c}\text { Paired } \\
\text { standard } \\
\text { deviation }\end{array}$ & $\mathbf{t}$ & $\begin{array}{c}\text { Significance } \\
\text { level }\end{array}$ \\
\hline $\begin{array}{l}\text { Before evaluation } \\
\text { of motion and } \\
\text { time }\end{array}$ & 12.94 & 3.19 & & & & & \\
\hline $\begin{array}{l}\text { After evaluation } \\
\text { of motion and } \\
\text { time }\end{array}$ & 19.67 & 3.53 & 137 & 0.27 & 4.33 & 0.75 & 0.46 \\
\hline
\end{tabular}

According to obtained results the observed $\mathbf{t}$ doesn't show a significant difference between average amount of supervision component before and after motion and time evaluation at level $\mathrm{P}<5 \%$. Thus, implementing motion and time evaluation plan can not affect supervision there fore fourth hypothesis is rejected.

Research hypothesis 5: Implementation of motion and time evaluation affects component of colleagues of job satisfaction.

Table 5- Results of dependent t-test, comparing average amount of scores before and after motion and time evaluation related to component of colleagues of job satisfaction

\begin{tabular}{|l|c|c|c|c|c|c|c|}
\hline \multicolumn{1}{|c|}{$\begin{array}{c}\text { Statistical } \\
\text { indexes }\end{array}$} & Mean & $\begin{array}{c}\text { Standard } \\
\text { deviation }\end{array}$ & df & $\begin{array}{c}\text { Paired } \\
\text { average }\end{array}$ & $\begin{array}{c}\text { Paired } \\
\text { standard } \\
\text { deviation }\end{array}$ & $\mathbf{t}$ & $\begin{array}{c}\text { Significance } \\
\text { level }\end{array}$ \\
\hline $\begin{array}{l}\text { Before evaluation } \\
\text { of motion and } \\
\text { time }\end{array}$ & 3.36 & 1.12 & \multirow{2}{*}{137} & 0.67 & 1.24 & 6.36 & 0.001 \\
\hline $\begin{array}{l}\text { After evaluation } \\
\text { of motion and } \\
\text { time }\end{array}$ & 3.98 & 0.97 & & & & & \\
\hline
\end{tabular}


According to obtained results the observed $\mathbf{t}$ doesn't show a significant difference between average amount of component of colleagues before and after motion and time evaluation at level $\mathrm{P}<5 \%$. Thus, implementing motion and time evaluation plan can not affect colleagues, there fore fifth hypothesis is confirmed.

\section{Discussion and conclusion}

Findings with regard to effectiveness level of executing motion and time evaluation on motion nature component of job satisfaction show ineffectiveness of motion and time evaluation on increasing of employees' positive attitude towards nature of the work they are performing. It will strengthen cases such as interest in job, attaching more importance to job, worthiness of social basis of job, representing viewpoints to determine organizational purposes, feeling of clarification in opportunities and expectations of the organization in employees. Although obtained data from average of questions before and after executing motion and time evaluation shows that attitude towards work nature among employees has been positive and they have had a positive attitude with regard to their work nature but this positive attitude hasn't been strengthened after motion and time evaluation. In this regard Ettil (2006) demonstrated in his studies that motion and time evaluation could affect job satisfaction when it is done favorably and completely and if this evaluation is implemented by management, it could increase job satisfaction.

Obtained results of motion and time evaluation and its effectiveness on wage component of job satisfaction indicate the effect of motion and time evaluation on it. In other words, executing motion and time evaluation causes employees to have more fair attitude towards the proportionality of their wage and benefits with life expenditures as well as their competence level. One of the main issues of work evaluation is that it determines standards of performing work for employees. Accordingly, existence of work standards causes people to perceive that to what extent their work has been matched with such standards and could be along with purposes of the organization before and after motion and time evaluation.

Therefore, motion and time evaluation can establish more realistic attitude in employees with regard to wage and salary. So they try harder in the organization towards its purposes. Schein (2006), Moberg (2008), Edgar (2001), Gordon (2003) and Cordlle (2005) demonstrated that motion and time evaluation will help employees perceive their 
tasks better in the organization. Because so, their attempt will become purposeful and will proceed along with purposes of the organization.

Findings about comparing component of job promotion opportunity and job satisfaction before and after motion and time evaluation revealed that there was no significant difference among amount of job promotion opportunity in employees' viewpoint. In other words, motion and time evaluation could not be effective on cases such as freedom of action in work, opportunity to obtain higher posts based on competency and merit, observance of removal and nomination conditions, feeling the existence of probability of progress in job and feeling of attaching importance to employees' supervision in organizational decisions that provide the grounds of job promotion among employees.

Robbins (1998) illustrated in his studies that if justice and promotion exist in the organization based on competency, job satisfaction will be enhanced and motion and time evaluation could be one of the important tools in this regard, because this method ranks individuals according to competency and job capability and provides the possibility of their promotion.

Results obtained about comparing average satisfaction with regard to supervision before and after motion and time evaluation show that there is no significant difference among them. In other words, motion and time evaluation has no impact on observing and indiscrimination in relations to authorities with subordinates, good behavior of the direct supervisor, scientific and professional competency of supervisors and access level to higher level managers and employees' supervision has been similar before and after motion and time evaluation. About averages it shows that employees' satisfaction from supervision is relatively suitable and they have had a positive evaluation with regard to behavior of supervisors. Thus motion and time evaluation has no impact on this assessment.

Findings about comparison of colleagues from job satisfaction before and after motion and time evaluation reveal that there is a significant difference among satisfaction level of employees. In other words, motion and time evaluation has had no impact on satisfaction of its employees and their job value and credit hasn't been exhibited more among the colleagues. This is while Andrew (2006) and Smith (1996) represented positive reports about effectiveness of motion and time evaluation on increased efficiency of companies and organizations in their studies with regard to motion and time. They reported that motion and time evaluation is a factor which decreases prices and prevents random 
deviations in hardware systems but it appears that work and time evaluation could be effective on software systems of organizations especially human force as well. 


\section{References}

Andrew Dubrin, (2006) Ireland Duane and Williams Clifton, Management and Organization, south western publishing co. Cincinati, Ohio.

Cordell D.M, (2006) Risk Aok: How to Evaluate Risk Tolerance, Journal of Financial planning, Denver.

Ettili, J.E, Ernesto R.M, (2006) organizational Integration and process Innovation, Academy of Management Journal, Vol33, No 4.

Gordon George G., (2006) Industry Determinats of organizational culture, Vol.16, No2.

Luthans Fred, (1998) Organizational Behavior, $4^{\text {th }}$ ED, Singapore: Nc Graw-Hill.

Moberg D.J, (2008) Helping Subordinates with their personal problems: Amoral dilemma for managers, Journal of Business Ethics, vol 9.

Robbins Stephen P, (1998) organization Behavior, Eighth edition, prentice-Hall International.

Schein, Edgar, (2006) American psychologist, vol45.

Smith P.C and Kendal I.M, (1998) the measure of satisfaction in work and Retirement, Mounlly Chicago. 